\title{
Acknowledgment to Reviewers
}

Journal AGRARIS Vol. 6 No. 2 July-December 2020

Contibution from the following reviewers in this issue was much appreciated for their valuable review comments:

1. Titik Ekowati, Diponegoro University, Indonesia

2. Sri Kuning Retno Dewandini, Department of Agribusiness Universitas Janabadra, Indonesia

3. Ujang Paman, Department of Agribusiness Universitas Islam Riau, Indonesia

4. Suprehatin, Department of Agribusiness, IPB University, Indonesia

5. Mohammad Rondhi, Department of Agribusiness, Faculty of Agriculture, Jember University

6. Sofa Nur Azizah, Indonesia

7. Minyahil Alemu, Jimma University, Ethiopia

8. Edy Prasetyo, Diponegoro University, Indonesia

9. Destyana Ellingga Pratiwi, Faculty of Agriculture Brawijaya University, Indonesia 


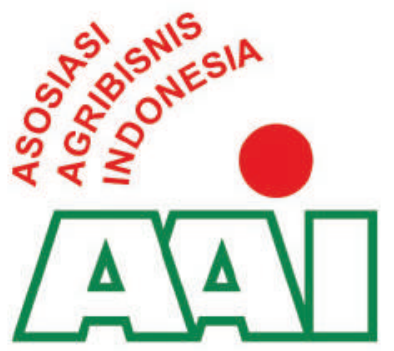

Agribusiness Association of Indonesia (AAl) is an academic organization on agribusiness field that aims to accelerate the relevance of studies, research, publications, and the development of competitive and sustainable agribusiness enterprises in Indonesia.

\section{AERARTS}

Journal of Agribusiness and Rural Development Research

AGRARIS is a periodical of scientific journals on Agribusiness and Rural Development that used as a medium to disseminate the research information of lecturers, researchers, and practitioners. AGRARIS is published twice a year (January-June and JulyDecember) by the Department of Agribusiness, Faculty of Agriculture, Universitas Muhammadiyah Yogyakarta in collaboration with Agribusiness Association of Indonesia (AAI).

\section{Vol.6.2 July-December 2020}

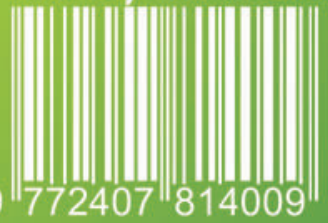

